\title{
The Passway of Women Entrepreneurship: Starting from Social Capital with Open Innovation, through to Knowledge Sharing and Innovative Performance
}

\author{
Made Setini ${ }^{1, *}$, Ni Nyoman Kerti Yasa ${ }^{2}$, I Wayan Gede Supartha ${ }^{2}$, I Gusti Ayu Ketut Giantari ${ }^{2}$ \\ and Ismi Rajiani ${ }^{3}$ (D) \\ 1 Doctoral Program, Faculty of Economics and Business, Udayana University, Denpasar, Bali 80361, Indonesia \\ 2 Lecture Department of Management, Faculty of Economics and Business, Udayana University, Denpasar, \\ Bali 80361, Indonesia \\ 3 Department of Management, Faculty of Economics \& Business, Universitas Muhammadiyah Gresik, \\ Jl. Sumatra 101 Gresik, Jawa Timur 61121, Indonesia \\ * Correspondence: made.setini@student.unud.ac.id
}

Received: 12 February 2020; Accepted: 8 April 2020; Published: 17 April 2020

\begin{abstract}
Customs and culture should create women's independence to actualize themselves in an era of emerging social progress in order to lead to the domination of women in the development of creative businesses. This research examines the role of social capital and whether it becomes a supporting or hindering factor in developing the creative industry of women entrepreneurs by examining the role of information sharing and innovations. Employing purposive sampling, questionnaires were distributed to 200 women entrepreneurs, and data were analyzed by using Structural Equation Modeling(PLS-SEM)software with SmartPLS Version 3.0. Social capital has a positive influence on the business performance of women entrepreneurs in Bali, Indonesia. Thus, the beliefs and norms that exist in the social capital of the Balinese Hindu concept can filter the information obtained from various information in business, which will ultimately be utilized by women entrepreneurs to create various innovations to meet the market demand. However, opportunities for women entrepreneurs are very limited to capital due to lack of guarantees to get capital, and a lack of entrepreneurship skills in the technological era, market access, bureaucracy, and legalization. Further, managerial skills, access to information technology, as well as the perspective that the men must be superior in Balinese culture and customs, make business for women entrepreneurs limited.
\end{abstract}

Keywords: social capital; knowledge sharing; innovation; women entrepreneurs

\section{Background}

Women have been debated for several decades to be a predictor of entrepreneurship [1,2]. Although entrepreneurship has been considered as the prosperity foundation of many countries, it has not been fully exploited with more significant opportunities for women [3]. Women entrepreneurs in Indonesia have supported the country's economic progress and prosperity [4], and it was mainly during the financial crisis in 1998 when women's entrepreneurship began to emerge for various reasons [4]. Likewise, on Bali Island, which is part of Indonesia, Balinese culture adopts a male-centric culture that requires men to be more dominant than women [5]. However, with the emancipation of women in 1930 [6], Balinese women have become recognized in various sectors, such as education, social, and trade [7].

In social life, Balinese women are required to adjust themselves to a tradition that prioritizes togetherness, making opportunities for Balinese women to establish a business [8]. Performing a dual role, Balinese women are responsible for family survival and improving family economic conditions [7]. 
This makes more Balinese women enter the informal sector when starting their businesses because, in the informal sector, it is more comfortable to play a dual role. Women entrepreneurs in Bali have increased every year, especially in Denpasar, the capital of Bali, which has experienced growth in the past five years, making a 69\% contribution to the economy of Bali [8]. In 2018, SMEs in Bali included 570 successful entrepreneurial endeavors by young people, and universities have also activated their business incubation programs to produce more new young entrepreneurs [9].

Ritual and cultural activities in Bali contribute to the business opportunities by Balinese women, who generate exceptional employment and abilities in tourism sustainable through entrepreneurship [2]. Balinese women entrepreneurs show "matrifocality", which means they act as business and family leaders [7]; in other words, women entrepreneurs in Bali are not only in business but also in the social order. However, most women in Bali have not yet found the right access to push their business to the international level [10].

Environmental, cultural, and inheritance factors influence entrepreneurial intentions among Balinese women entrepreneurs [11], as well as social capital [12]. The existence of togetherness activities, "menyama braya" or equalizing, in customs or other events in Bali create business opportunities [3] since they will indirectly build a network of togetherness. The interaction of many people will undoubtedly make the role of business in the market in the form of social capital [13]. According to data from the 2018 Bali Statistics Agency, the culinary business has experienced rapid progress up to $40.72 \%$, followed by the clothing industry $28.27 \%$ and the service sector $18.80 \%$, and the rest are other sectors, including crafts. The issuance of Balinese government policy on the use of traditional and culinary clothing in the Bali tourism sector has apparently made a great opportunity for fashion and culinary businesses.

Social capital has a positive influence on women entrepreneurs in Bali [11] because it can make the communication process more manageable and ensure that it has business value. Building networks make a vital process of sharing information and providing access to resources and knowledge [14]. Substantial social capital makes it easy to exchange ideas, give rise to creative innovation ideas $[15,16]$, and share information simultaneously, which ultimately improves the business performance of women entrepreneurs $[17,18]$. Mat Songoni and Mutambara pointed out that having very limited opportunities and gender differences in social capital put women entrepreneurs in a marginal status [19].

In a developing country, the debate on how to encourage more women entrepreneurs keeps on going as genders affect entrepreneurial decisions [1,2]. In this regard, social capital is not able to be a driver of progress in creative endeavors [12,20-22]; another hierarchy is needed, as set by Ghosal [23], where cultural diversity has different ways of encouraging creative industries. Social capital does not have a positive impact on innovation on women entrepreneurs [24]. Relatively little attention has been given to women entrepreneurs, especially for developing countries like Bali, Indonesia [11]. Balinese culture is synonymous with togetherness, making researchers want to rethink the role of social capital on the part of businesswomen entrepreneurs in Denpasar, which notably provide many employment opportunities.

This paper is composed of six chapters. The first chapter is an introduction, and the second is the literature review and hypotheses. Section 3 discusses the data and methodology, Section 4 presents the analysis results, and Section 5 provides discussions. Finally, Section 6 describes the conclusions of the findings and provides recommendations for practice and further studies.

\section{Theory and Hypotheses}

\subsection{Open Innovation and Women Entrepreneurs}

Women entrepreneurs are defined as women involved in independent business decisions related to managing business [25], identifying, developing, and carrying that vision into innovative ideas to create opportunities with a better way of doing things [26]. The views of women entrepreneurs focus on the power to control their business in creating innovative products expected by the market, absorbing as much information as possible, as well as improving relationships with businesses, suppliers, and 
consumers [27]. Characterization of women in business recommends the recognition of women as equal legs and arms in business for the value of commitment or ability, information, and capacity they carry on [28]. Although women's business levels are growing, there is still little research on women entrepreneurs, especially in developing countries [2,22,24,25,29].

Bali's tourism sector has been thriving because of the role of Balinese women entrepreneurs in engaging ritual activities for tourists and contributing to tourism-based businesses in opening up employment opportunities [11]. The support of Balinese women in the casual division is unique because of their emphasis on the food, clothing, and service businesses that they offer to travelers. Bali is famous for its extraordinary ability to contribute to the development of sustainable tourism entrepreneurship, such as the culinary industry, indicating that Balinese women entrepreneurs must be able to manage business and families [8]. Denpasar is the center of the city of Bali, where many informal and challenging business sectors are found. This informal sector, due to its highly complex urban areas, requires dynamic management [29]. Women's work in the Balinese economy has been increasingly significant over the years, and ambitious women's work has become an important part of the economy [11].

Gradually, open innovations are carried out by individuals or women's networks in Denpasar, Bali; open innovations are formed with the help of the dynamic role of industry, government, training institutions, and the community environment [30]. This creative industry of female entrepreneurs continues to follow the trend of technological progress by adopting an open platform to maintain an ongoing innovation environment [30]. Training institutions and government provide support to women entrepreneurs in Bali by being proactively involved in various fields, from training on finances and technology transfer to the joint creation of knowledge [31].

In 2019, many women entrepreneurs in Denpasar received support from the government, and much training was held to broaden the horizons of business people. Various government support programs for the development of SMEs in Bali have also been conducted, ranging from training to workshops. The progress of women in management and entrepreneurship has been a major step in increasing the participation of Balinese women in the process of economic development, creating employment opportunities and improving their economic, social, educational and health status, and family life $[2,11,32,33]$. This support has came from many parties such as Google, Bekraf, and cooperatives. However, the contribution of women is still low, and their productivity is hindered by many factors, including the recognition toward women entrepreneurs (interview in 2019), limited capital, market access, bureaucracy and legalization, management ability, access to information technology, and changes in consumer tastes, making them less competitive in the market.

\subsection{Social Capital}

Social capital is a multidimensional concept [13,34-37], known as valuable assets for the protection and empowerment of organizations that depart from social network theory. Social capital as an intangible asset [33,37] that not only encourages innovative collaboration and interaction but also facilitates the learning process [38]. Social capital remains complex with various dimensions $[22,23,33,39,40]$.

The three dimensions of social capital are (1) structural dimensions, including network condensation and healthy relationships, (2) the relational dimensions, including trust and commitment, and (3) cognitive dimensions, including shared vision and organizational distance. Structural capital includes social relationships and networks that determine how to communicate with each other $[14,23,33]$. Factors in this dimension include network density, connectivity, and hierarchy. The strength of the relationship leads to the extent of the relationship between one party and another, and this factor advances the transition of the knowledge of organizational members [41]. Relational capital facilitates network relationships in terms of trust between people, shared norms, and identification by others in the network [42]. Cognitive capital consists of shared goals, vision, and values of organizational members [4]. Social capital is a private network that is divided into two, 
namely, external and internal capital [22], where external capital facilitates ease in obtaining credit, information about markets, and retaining customers. In contrast, internal capital is the support of family and friends [43].

In harmony with the Balinese culture that carries the concept of "menyama braya" or togetherness, making social capital an asset to obtain resources that can ultimately improve the quality or performance of women entrepreneurs in Denpasar, Bali. When a business visionary has a solid interpersonal organization that has similar qualities and beliefs, his business venture will have the option to appreciate the various assets provided by his organization through the level of financial and non-financial implementation.

\subsection{Knowledge-Sharing}

Sharing is adopted from "Toward a knowledge-based theory" [44]: tacit knowledge and explicit knowledge [35]. Tacit knowledge is more personal because it develops based on personal experience and, in general, it is difficult to formulate and to communicate because it is obtained through lineage, and one's experience [30]. Each entrepreneur must have different experiences based on unpredictable situations and conditions. Explicit knowledge is formal and systematic; it is easy to communicate and share $[14,30]$. Application of this knowledge is more straightforward because the knowledge is in the form of written or documented statements so that each entrepreneur can study them independently.

Knowledge turns information into a basis for action [16-18,45,46], which makes a person or institution take more effective engagements [47,48]. Sharing knowledge can simultaneously influence the abilities and competencies of individuals and organizations and strengthen organizational intellectual capital in the field of human and organizational capital [42,49-51].

Activities of gathering women are simple ways among women entrepreneurs to exchange knowledge and contribute to the application of knowledge [8,52]. The practice of sharing knowledge with women entrepreneurs is very important to get new information on how the process of self-improvement, new techniques and ideas, solving problems and creating core competencies, and starting new ventures [53-55].

In Denpasar in 2019, the success stories were shared with women entrepreneurs during training aimed at fostering entrepreneurial enthusiasm. Tacit sharing was done by listening to the experiences of innovative entrepreneurs who have succeeded as well as training conducted on how to become an entrepreneur [56-58]. The skills taught in training have included designing a product, service, and marketing in the technological era [59].

\subsection{Innovation}

In economic development, innovation is the driving force of economic growth [38]. Innovation is defined as a knowledge base to produce something useful and is a modification or discovery of ideas so that they can develop from business [34]. Innovation has an important role in modern social evolution, which is considered in some studies as an innovation-based economy [35-37]. Innovation can be interpreted as the business capability in offering new things in a better way and be able to compete in new markets or old markets [39]. There is no provision on how innovations in SMEs measure innovation itself based on subjective comparisons of SMEs, for example, in the existence of products and new services earlier than other companies [40]. Innovation in an organization is defined as innovative management and service practices. This ability can be the result of the talent and intelligence of people or the results of the training that will offer a new dimension or exploitation of new ideas from the personal or organizational side to strengthen entrepreneurship, enhance, develop, and explore existing competencies and provide new facilities [41,42].

Innovations are divided into three categories [16]: product innovation (designing more unique products or creating products), process innovation, and service innovation. Innovation has a very important role that has been shown, in previous research, as a whole to promote product excellence, 
competitiveness, profitability, and efficiency [38]. To achieve sustainable innovation, the norms and values of women entrepreneurs must be a concern alongside technology and innovation processes [34].

In Jaya's opinion [60], technology makes a product quickly imitated, so an entrepreneur must be able to maintain its unique design with good quality and fast artistry, such as fashion products that characterize local Balinese products. The governor of Bali emphasized that women entrepreneurs in Bali must be able to combine innovation and local culture [61].

\subsection{Relationship between Variables}

Business sectors on a small scale with limited capital can improve business performance by establishing links between entrepreneurs [15,37]. Social capital, like trust, support, and strategic advice, are important factors in women entrepreneurs as they can complement each other to ensure efficient and performed business. External social capital is a social relationship with customers, suppliers, creditors, and intangible resources that are rooted in trust, loyalty, and referrals, according to Akintimehin [22]. Internal social capital expresses social relationships with friends, family, business partners, and intangible resources $[14,15,22,49,50]$.

Social capital provides the success of sharing knowledge and innovation, allowing for combinations within a particular organization. The process of externalization and internalization play important roles in the transformation of two types of knowledge $[13,17,21]$. Social capital simplifies access to knowledge, increases the value of knowledge, and uses it to improve and is an important action for companies to succeed and survive. Social capital provides easy access to intellectual resources, so it becomes an important factor for improving the performance of business [18,43,50-52].

Sharing of knowledge between entrepreneurs will generate a process of transfer of self-upgrading, the formation of new organizational groups, the exchange of information, motivation for the development of entrepreneurs, and indirectly create an arena for promotions and networks. This will have a positive influence on the performance of businesswomen entrepreneurs [30,33]. In developing business activities, it is always necessary to communicate with each other. Sharing knowledge creates opportunities to utilize resources owned and the networks that can be mobilized. Resources are very important. These include (1) physical resources in the form of geographical and financial location, (2) human characteristics in terms of competence, innovation, skills, knowledge, superior sales force, (3) organizational features, namely, structure and culture, business processes, cost control systems, and (4) human resource systems, a type of capital that can be used to implement value creation strategies [37,54]. The difficulty of sharing knowledge is the willingness of information owners to disclose and share. This obstacle can be overcome by trusting a relationship in the process of sharing knowledge.

Women's entrepreneurship is recognized as a major distributor of job creation and innovation, and their participation in economic activities matching ownership and control of productive assets accelerates the development process and reduces poverty and inequality, while increasing the welfare of children as a whole [58]. Entrepreneurs as individuals will always try to develop the ability to be able to adjust to working together in an organization. The pattern of organized cooperation, ordered by specific objectives related to each other, is determined by the depth of the relationship pattern [55].

Social capital without suspicion and concealment during the provision of external and internal information to resources can be converted to new ideas for innovation. The local wisdom of Balinese culture embodied in the spirit of respect for individual rights, the spirit of working together, tolerance of differences of opinion is the basic capital that can be increased to become the foundation of social capital [40]. Social-communal changes that occur as a result of global markets is a dynamic process that will have an impact on opportunities, challenges, and successes of social change towards strengthening local values in strengthening social structures [11].

H1: Social capital influences the success of entrepreneurial performance.

H2: Social capital influences the success of innovation.

H3: Social capital has a positive influence on knowledge sharing. 
H4: Knowledge-sharing influences the success of innovation.

H5: Innovation influences the success of female entrepreneurial performance.

H6: Knowledge-sharing has a positive influence on entrepreneurial performance.

Based on a theoretical study and the results of previous studies and the modified model, the conceptual framework of the research is displayed in Figure 1.

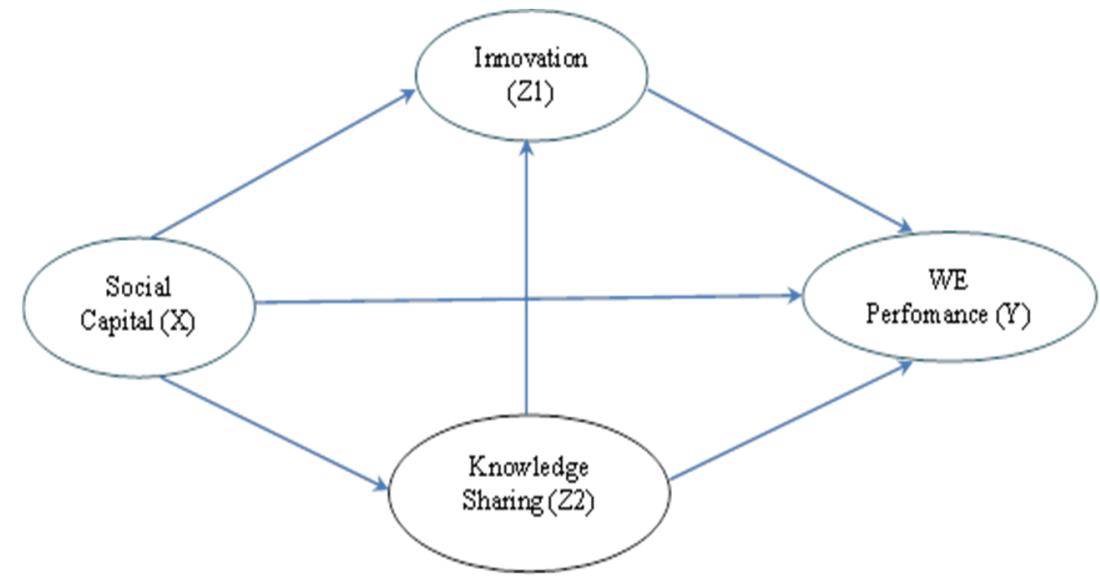

Figure 1. Research concept framework. Source: authors's own elaboration, Adoption of the model: $[20,21,54]$.

\section{Methods}

This study uses a quantitative approach because this research is based on a strong and reliable theory generalization [22], using the principle of positivism, namely, testing data and theories, through hypothesis testing, and it examines whether social capital, information sharing and innovation are supporting or inhibiting factors in women's entrepreneurship in Denpasar, Bali, Indonesia. Data is processed with the help of the [SmartPLS]. (Srikandi Cooperative, Denpasar Bali, Indonesia, 2019) application using SEM [22].

The data used are from informal business women entrepreneurs. Since the data of informal business entrepreneurs in Denpasar Bali are not known [56], it can only be said that informal businesswomen in Denpasar Bali are approximately $10 \%$ of the informal sector actors in Bali; the sampling technique applied is purposive sampling, which means sampling techniques with certain considerations [24]. The population used was the group of women who are members of a group of entrepreneurs in Denpasar with the following criteria: (1) business owners, with (2) businesses that have been established for one year. The sample of research respondents used amounted to 200 samples because, according to Hair and Black [23], the number of samples used should be 5 to 10 multiplied by the indicator, so that the sample of 200 was sufficient to represent women entrepreneurs in Denpasar.

Data collection was carried out by interview questionnaires directly to the women's small business unit in Denpasar, Bali, in early November 2019, and data obtained from the women's community were merged into one by the name of Srikandi Cooperative, Denpasar Bali, Indonesia, 2019. Questionnaires were given to women who were active in businesses such as culinary, fashion, services, and others, with a population of 350 people.

This study identifies social capital, knowledge sharing, and innovation as factors that influence women's small businesses in Denpasar, Bali. This study divides the questionnaire into four sections. The first part focuses on population demographic characteristics such as business number, business name, length of business, and number of employees. The second part is the business sector, marital status, education level, source of capital, initial capital, sales (years), and the third part is a question of variables used in this research, namely, social capital, information sharing, and innovation with women entrepreneurs in Bali. A Likert scale of 1 and 5 is used to measure (from 1 "strongly disagree" to 5 
"strongly agree"). The fourth part is a question or opinion section, which gives freedom to the informant to provide information on what other factors are supporting and inhibiting their business performance.

The questionnaire, which is divided in 4 sections, was distributed to the entire population of women entrepreneurs and firstly has questions to find out if they are eligible to participate in the survey due to the survey requirements that ask that they must have been in business for over a year, have more than 2 employees, and operate in an informal business status. The second part of the survey is to find out the business sector and the productive age of entrepreneurs. The third part is to find out how much influence between the variables on the business performance of women entrepreneurs in Denpasar, Bali, and, finally, the fourth part questions other factors besides support and inhibitions. From the first part of the questionnaire given, only 200 samples met the criteria for analysis.

The indicators used in this study were adopted from several previous studies in forms of structural, beliefs, norms, and cognitive [25-27]. The information-sharing indicator was adopted by Karlsen, Hagman [28], which divides knowledge-sharing into two, namely tacit and explicit, which are divided into constructs [29]. To measure innovation, Sanchez-Famosos, Dastourian, and Agyapong's research was used. The measurements used in this study are developing new products, introducing new service concepts, making industries more creative, using a unique marketing system $[13,16]$.

Data processing and analysis will be carried out with the help of Smart PLS software, and resampling (bootstrapping) where the steps to be carried out are (1) designing the measurement model (outer model), and (2) designing the structural model (inner model), (3) constructing a path diagram, (4) converting a path diagram into equations in the outer model and the inner model, (5) parameter estimation, (6) the model fit test, and (7) testing hypothesis and discussion [23].

\section{Results}

The number of data taken is the 200 people who filled the answers from the questions. Of the respondents, 70 are in the culinary sector $(35 \%), 55$ in the fashion sector $(27 \%)$, service sector $45(22.5 \%)$, and $30(15 \%)$ in other sectors. This means that the creative industry, which is more in demand by women entrepreneurs in Denpasar, is the culinary sector, as seen in Table 1.

Table 1. Descriptive data.

\begin{tabular}{ccc}
\hline Group & Frequency & $\%$ \\
\hline Culinary & 70 & 35 \\
Mode & 55 & 27.5 \\
Service & 45 & 22.5 \\
Others & 30 & 15
\end{tabular}

Source: Authors' calculations from data collected in 2019.

The majority of the respondents (130; 65\%) were married, 65 (32.5\%) were single, $5(2.5 \%)$ divorced. The results show that the research subjects are mostly married since it is possible those who are married have more capital and needs the cost of living. Additionally, financial need encourages them to become entrepreneurs. The status of being single also creates a rather large entrepreneurial desire as there is a desire for independence and freedom of time.

Women entrepreneurs are more dominated by productive ages between 30 until 45 years. Briefly, $65 \%$ of millennials are more productive in the industry creative as at this age; they have more energy to receive new learning in the technological era. Besides, those in productive ages are more ambitious and not resistant to new challenges. This is certainly interesting as there will be many young people with businesses and young independent people in Denpasar, Bali. The findings also show that in Denpasar, the majority $(70 \%)$ of the respondents have an undergraduate education level, $15 \%$ of them have a high school level, $10 \%$ have a master degree, and 5\% have doctoral degrees. Entrepreneurial groups, mostly with undergraduate-level education, have a higher desire for the freedom of time and 
dual roles, making them choose the field of business $[10,26]$. On the other hand, secondary education holders choose entrepreneurship because of the difficulty of securing jobs [61], while the educated master degree holders want to make additional financial income [10].

Most of the respondents running their business are still relatively new, between 1 and 4 years, in line with the productive age of young entrepreneurs. They have 1 to 4 employees, with an initial capital of around Rupiah 5 to 10 million. All of these entrepreneurs were still in an informal status because they were still not legally registered.

Converting validity with reflective indicators can be seen from the correlation between indicator scores and external loading variables. Scores of $>$ AVE 0.50 or greater indicate the model is good and all constructs used in the study have adequate discriminant validity [30] Likewise, the value of Cronbach's alpha is required above 0.60 , as well as significance at the $t$-test $5 \%$ ( $t$-statistic value $>1.96$ or $p$-Value $<0.5)$. The value of composite reliability (CR) of each constructare all expected to be more than 0.7 to meet the construct reliability requirements [30]. Measurements indicate that all indicators are valid and feasible to be used for analysis in the structural model (inner model). Appearance of questionnaire validity and reliability in Table 2.

Table 2. Test validity and reliability.

\begin{tabular}{|c|c|c|c|c|c|}
\hline $\begin{array}{l}\text { Variables/ } \\
\text { Indicators }\end{array}$ & $\begin{array}{c}\text { Outer } \\
\text { Loading }\end{array}$ & $\begin{array}{c}\text { Average Variance } \\
\text { Extracted (AVE) }\end{array}$ & $\begin{array}{l}\text { Composite } \\
\text { Reliability }\end{array}$ & $\begin{array}{l}\text { Cronbach's } \\
\text { Alpha }\end{array}$ & Explanation \\
\hline \multicolumn{6}{|l|}{ Social Capital } \\
\hline $\mathrm{SC} 1$ & 0.822 & \multirow{3}{*}{0.658} & \multirow{3}{*}{0.848} & \multirow{3}{*}{0.74} & \multirow{3}{*}{$\begin{array}{l}\text { Valid and } \\
\text { Reliable }\end{array}$} \\
\hline SC2 & 0.817 & & & & \\
\hline SC3 & 0.975 & & & & \\
\hline \multicolumn{6}{|l|}{ Knowledge } \\
\hline Sharing & 0.713 & \multirow{5}{*}{0.536} & \multirow{5}{*}{0.852} & \multirow{5}{*}{0.578} & \multirow{5}{*}{$\begin{array}{l}\text { Valid and } \\
\text { Reliable }\end{array}$} \\
\hline KNS3 & 0.74 & & & & \\
\hline KNS3 & 0.717 & & & & \\
\hline KNS4 & 0.803 & & & & \\
\hline KNS5 & 0.683 & & & & \\
\hline \multicolumn{6}{|l|}{ Innovation } \\
\hline IN1 & 0.679 & \multirow{5}{*}{0.527} & \multirow{5}{*}{0.869} & \multirow{5}{*}{0.777} & \multirow{5}{*}{$\begin{array}{l}\text { Valid and } \\
\text { Reliable }\end{array}$} \\
\hline IN2 & 0.686 & & & & \\
\hline IN3 & 0.729 & & & & \\
\hline IN4 & 0.752 & & & & \\
\hline IN5 & 0.799 & & & & \\
\hline \multicolumn{6}{|l|}{ Performance } \\
\hline Enter1 & 0.783 & \multirow{5}{*}{0.571} & \multirow{5}{*}{0.852} & \multirow{5}{*}{0.810} & \multirow{5}{*}{$\begin{array}{l}\text { Valid and } \\
\text { Reliable }\end{array}$} \\
\hline Enter2 & 0.706 & & & & \\
\hline Enter3 & 0.819 & & & & \\
\hline Enter4 & 0.798 & & & & \\
\hline Enter5 & 0.673 & & & & \\
\hline
\end{tabular}

Testing structural models (inner model) use the R-square for variable dependence (endogenous), and its significance value is tested based on the $t$-value at each path (path). The inner model is observed by looking at the relationship between latent constructs by analyzing the results of the estimated path coefficient and its significance level. The values of R-square between 0.67 to 1 indicate that the model is good. In contrast, the vulnerable value of $R$-square between 0.34 to 0.66 indicates a moderate structural model, and if the value of R-square is 0.33 or below, the structural model is considered weak [31].

In the structural model, there are tree dependent variables, namely, social capital, innovation, knowledge sharing, and the performance of women entrepreneurs (WE). The coefficient of determination $\left(\mathrm{R}^{2}\right)$ of each dependent variable is presented in Table 3 below. 
Table 3. Value Coefficients of R-square.

\begin{tabular}{ccc}
\hline Variable & R-Square & R-Square Adjusted \\
\hline Innovation $(\mathrm{Z} 1)$ & 0.519 & 0.509 \\
\hline Knowledge Sharing $(\mathrm{Z} 2)$ & 0.490 & 0.484 \\
\hline Performance WE $(\mathrm{Y})$ & 0.735 & 0.727 \\
\hline
\end{tabular}

Based on Table 3, the innovation variable has the R-square value of 0.519 , which means that $51.9 \%$ of innovation can be explained by the variables of social capital and information sharing. In comparison, the remaining $48.1 \%$ is explained by other variables outside the study. Furthermore, the R-square value for sharing information is R-square 0.490 , which means that $49 \%$ of the information sharing variable is influenced by social capital. In comparison, the remaining $52 \%$ is influenced by other variables. Finally, the R-square value for the performance of entrepreneurs women is 0.735 , which means that $73.5 \%$ of the performance variable is explained by the innovation, knowledge sharing, and social capital variables. At the same time, the remaining $36.5 \%$ is influenced by other variables.

The goodness model is also measured by using the predictive relevance of Q-square for the structural model to measure how well the observational values generated by the model and the parameter estimation. Values of Q-square $>0$ indicate the model has predictive relevance; conversely, Q-square value $\leq 0$ indicates the model lacks predictive relevance.

$\mathrm{Q}^{2}$ or the Stone Geisser $\mathrm{Q}-$ Square test requires that $\mathrm{Q}^{2}$ has a value in the range $0<\mathrm{Q}^{2}<1$, where closer to 1 means the model is better.

$$
\mathrm{Q}^{2}=1-\{(1-\mathrm{R} 1)(1-\mathrm{R} 2)(1-\mathrm{R} 3) ; 1-(1-0.519)(1-0.490)(1-0.735)=0.9
$$

The calculation results obtained are 0.9 , so it can be concluded that the model has a very good predictive relevance as 90 percent of women's entrepreneurial performance in Denpasar Bali is influenced by the variables of innovation, knowledge sharing, and social capital. In comparison, the remaining 10 percent is influenced by other variables.

\section{Discussion}

The measurement model (outer model) according to Figure 2. The direct influence between all variables can also be seen from the results of the validity test on each path coefficient as well as results of bootstrapping, as shown below:

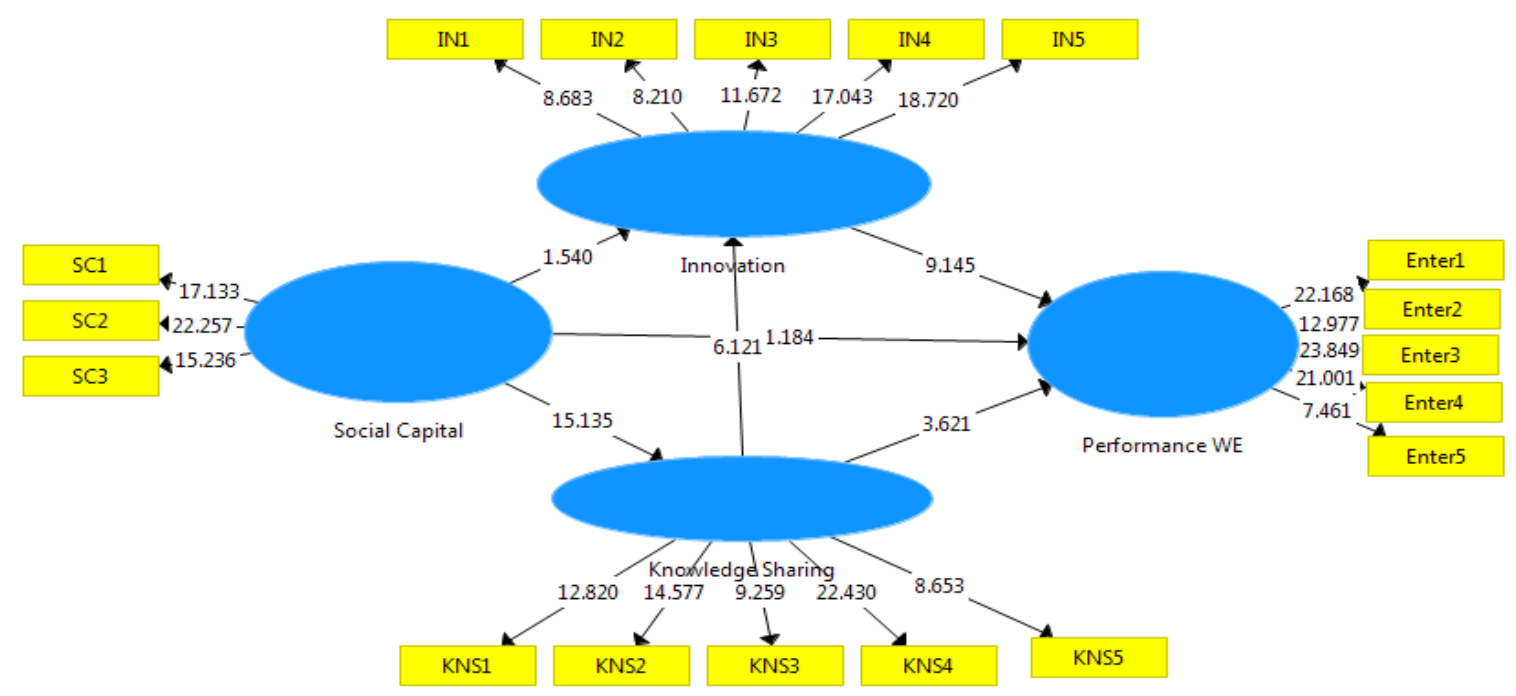

Figure 2. Empirical research model. Source: authors' calculations. 
The research hypothesis referred to Table 4 is as follows:

Table 4. Path Coefficients.

\begin{tabular}{ccccc}
\hline Between Path Variables & Coefficient & $t$ Statistics & $p$-Value & Information \\
\hline Social Capital $(\mathrm{X}) \rightarrow$ Performance WE $(\mathrm{Y})$ & 0.081 & 1.181 & 0.000 & $\begin{array}{c}\text { Positive and } \\
\text { Significant }\end{array}$ \\
\hline Social Capital $(\mathrm{X}) \rightarrow$ Innovation $\left(\mathrm{Z}_{1}\right)$ & 0.163 & 1.540 & 0.000 & $\begin{array}{c}\text { Positive and } \\
\text { Significant }\end{array}$ \\
\hline Social Capital $(\mathrm{X}) \rightarrow$ Knowledge Sharing $\left(\mathrm{Z}_{2}\right)$ & 0.700 & 15.135 & 0.000 & $\begin{array}{c}\text { Positive and } \\
\text { Significant }\end{array}$ \\
\hline Knowledge Sharing $\left(\mathrm{Z}_{1} \rightarrow \rightarrow\right.$ Innovation $\left(\mathrm{Z}_{1}\right)$ & 0.597 & 6.121 & 0.000 & $\begin{array}{c}\text { Positive and } \\
\text { Significant }\end{array}$ \\
\hline Innovation $(\mathrm{Z} 2) \rightarrow$ WE Performance $(\mathrm{Y})$ & 0.585 & 9.145 & 0.000 & $\begin{array}{c}\text { Positive and } \\
\text { Significant }\end{array}$ \\
\hline Knowledge Sharing $\rightarrow \rightarrow$ Performance of WE $(\mathrm{Y})$ & 0.272 & 3.621 & 0.000 & $\begin{array}{c}\text { Positive and } \\
\text { Significant }\end{array}$ \\
\hline
\end{tabular}

\subsection{Social Capital Affects the Performance of Women Entrepreneurs (WE)}

The direct effect of social capital research on the performance of women entrepreneurs, as shown in Table 4, shows that the path coefficient is 0.081 , with a significance value of 0.000 . The HI hypothesis is accepted, so it can be said that the increase in social capital with the indicators used results in an increase in the performance of women entrepreneurs in the city of Denpasar. Balinese culture that believes in the teachings of "Tri Kaya Parisudha"—-think good, say good, and do good [32]—making norms and trust between business people, making easier to communicate and reduce disputes between groups, in line with previous research [13-15], but this is refuted by other researchers [26,33-37] stating that close relationships tend to be a source of division in the industry in Ethiopia, South Korea, Nigeria, India, and Central Java Indonesia.

\subsection{Social Capital Influences Innovation}

The direct influence of social capital research on innovation, as shown in Table 4, shows that the path coefficient is 0.163 , with a significance value of 0.000 . The $\mathrm{H} 2$ hypothesis is accepted, so it is concluded that increasing social capital, combined with the culture [33], will be able to provide creative ideas for innovation. In Bali, the governor enacted regulation No. 79/2018, compelling Balinese custom culture, cultural-based products with innovation and creativity by the vision of the Bali provincial government "Nangun Sat Kerti Loka Bali", to maintain Balinese harmony in line with research. Through good relations, mutual trust, and mutual respect, individuals and business groups are willing to exchange as well as combine knowledge to produce innovation. The form of new capabilities, new ways of working, new perspectives, or new products as a competitive advantage is supported by previous research $[15,16]$ emphasizing that creativity and innovation cannot be put aside when explaining the growth of the industrial sector in the economy in Ghana, but is also not in line with other research $[12,20,36]$.

\subsection{Social Capital Has a Positive Effect on Knowledge-Sharing}

The direct effect of social capital research on knowledge sharing, as shown in Table 4, shows that the path coefficient is 0.700 , with a significance value of 0.000 . The H3 hypothesis is accepted; networking has a positive impact on the ease of information resources, suppliers, workshop information, and other information. Social capital, such as local wisdom, can advance the creative industry in Denpasar, Bali. Local wisdom can enrich the industrial sector with "conferences, meetings, workshops, and exhibitions" so that these women entrepreneurs can learn and develop themselves from local wisdom. This finding supports previous findings $[16,17,33,38,39]$. 


\subsection{Knowledge-Sharing Has a Positive Effect on Innovation and Performance of Women Entrepreneurs}

The direct influence of knowledge-sharing on innovation and knowledge-sharing on the performance of women entrepreneurs in Bali is shown in Table 4. The path coefficients are 0.597 and 0.272 , respectively, with a significance value of 0.000 , meaning hypotheses $\mathrm{H} 4$ and $\mathrm{H} 6$ are accepted. The women entrepreneurs in Denpasar have often participated in pieces of training organized by the government or private parties, or among women entrepreneurs themselves, sharing stories about product design ideas that they can share with their other colleagues. Training and workshops increase their knowledge and ultimately influence innovation patterns, supporting the previous research $[13,17,40]$; however, different opinions with other researchers also exist [16].

\subsection{Innovation Has a Positive Influence on the Performance of Women Entrepreneurs}

The direct effect of innovation on the performance of women entrepreneurs, as shown in Table 4 , indicates that the path coefficient is 0.585 , with a significance value of 0.000 . Hypothesis $\mathrm{H} 5$ is accepted; innovation raises local cultural wisdom in designing and packaging products as well as branding in building consumer confidence. The training obtained made these women entrepreneurs capable of making unique and exciting product innovations. Bali is famous for its handicraft sector, which has a distinctive character that has been enhanced with the training provided by the government to convert this tradition and culture into innovative products. These findings support previous findings $[15,20,41,42]$.

\section{Conclusions and Recommendations}

Previous studies of social capital have posed varied problems. However, this occurrence does not happen in the study of women entrepreneurs in Bali, who hold the concept of culture and the teachings of Hindu "Tri Kaya Parisuda" (say, think and do good), making social capital the norm. In the future, network relations are more differentiated in the direction of objectives of social capital, so further analysis should consider addressing the various interests of social capital at various levels. A network that is too much will also hurt the exchange of information that occurs, so there is a need to group networks according to the occupied business sector.

In terms of management, SMEs still need intensive coaching regarding company management, especially in terms of ownership, financing, and profits. This guidance is crucial so that everything in SMEs can be structured properly in terms of planning, organizing, activating, and control. SMEs must be fully committed to applying the principles of modern business in their business activities, including separating corporate finance from personal or family finances.

Innovation is not only carried out in the product sector but also in the marketing sector. Since SMEs in Bali still market the product conventionally, it is imperative for the SMEs to update their marketing skills through social media. SMEs are expected to understand digital marketing channels according to the objectives and characteristics of their products and know the tricks to bring in more visitors, followers, and buyers.

The open innovation of the UKM Wanita Denpasar, Bali, will enrich the sustainability content following the concept of culture in Bali of "Tri Hita Karana " and "Nangun Sat Kerti Loka Bali", which have become a foothold and are the same as the concept of the triple-bottom-line of economic sustainability, social level, and the environment [54]. In the effort to develop SMEs, it is inseparable from various problems arising from the difficulty in accessing various economic resources, including the lack of people who like SME products, in socialization of the use of local products reflected; there may still be a lack of desire to develop SMEs in the regions. It must be admitted that the SMEs should have a place in the hearts of the community to trigger the initial intention of SMEs to preserve local wisdom through the works and crafts marketed.

Author Contributions: Conceptualization, M.S.; methodology, M.S.; software, M.S.; validation, N.N.K.Y., IG.A.K.G., and I.R.; formal analysis, N.N.K.Y., IW.G.S., IG.A.K.G., and I.R.; investigation, M.S., N.N.K.Y., IW.G.S., 
IG.A.K.G., and I.R.; resources, M.S.; data curation, M.S.; writing-review and editing, M.S.; visualization, M.S.; supervision, IW.G.S.; project administration, M.S., N.N.K.Y., IW.G.S., IG.A.K.G., and I.R.; funding acquisition, M.S., N.N.K.Y., IW.G.S., IG.A.K.G., and I.R. All authors co-operated in completing this paper and All authors have read and agreed to the published version of the manuscript.

Funding: This research received no external funding.

Acknowledgments: We are very grateful to the UKM community in Bali which is incorporated in one forum, making it easier for me to collect data. The authors owe deeply appreciations to I Made Artana, S.Kom, M.M. (Chair of STMIK Primakara), Agoes Ganesha Rahyuda S.E., M.T., Ph.D (Dean of Faculty of Economics and Business, Udayana University), I Wayan Gede Supartha, S.E., S.U. (Chair of Management Science Doctoral Study Program, Udayana University).

Conflicts of Interest: The authors declare no confict of interest.

\section{References}

1. Dean, H.; Larsen, G.; Ford, J.; Akram, M. Female Entrepreneurship and the Metanarrative of Economic Growth: A Critical Review of Underlying Assumptions. Int. J. Manag. Rev. 2017, 21, 24-49. [CrossRef]

2. Kusumawardani, K.A.; Widyanto, H.A.; Deva, I.P.L.I. Understanding the Entrepreneurial Intention of Female Entrepreneurs in the Balinese Tourism Industry. Int. J. Res. Bus. Soc. Sci. 2020, 9, 63-79. [CrossRef]

3. Neumeyer, X.; Santos, S.C.; Caetano, A.; Kalbfleisch, P. Entrepreneurship ecosystems and women entrepreneurs: A social capital and network approach. Small Bus. Econ. 2018, 53, 475-489. [CrossRef]

4. Tambunan, T.T.H. Women Entrepreneurs in MSEs in Indonesia: Their Motivations and Main Constraints. Int. J. Gend. Women Stud. 2017, 5, 56-86. [CrossRef]

5. Laksana, I.G.N.D.; Jayantiari, I.G.A.M.R. Implementation Model of Share Farming Agreements of Customary Land in Bali (A Study on Indigenous People's Legal Culture). J. Law Policy Glob. 2019, 85, 31-36.

6. Putra, I.N.D. Masih Identik Dengan Peran Domestik? Implikasi Perkembangan Pariwisata Pada Dinamika Relasi Gender di Bali; IHDN Press: Denpasar, India, 2018.

7. Handayani, R.; Wahyudi, S.; Suharnomo, S. The effects of corporate social responsibility on manufacturing industry performance: The mediating role of social collaboration and green innovation. Bus. Theory Pract. 2017, 18, 152-159. [CrossRef]

8. Adhiputra, M.W. Kewirausahaan Mandiri Perempuan Berbasis Kearifan Lokal dan Filosofi Hindu di Bali. Jurnal Riset Ekonomi dan Manajemen 2018, 16, 237-246. [CrossRef]

9. Aripurnami, S. Transformasi Gerakan dan Menguatnya Kepemimpinan Perempuan. Tentang Penulis 2013, 2, 2089-2091.

10. Tajeddini, K.; Ratten, V.; Denisa, M. Female tourism entrepreneurs in Bali, Indonesia. J. Hosp. Tour. Manag. 2017, 31, 52-58. [CrossRef]

11. Weiss, J.; Anisimova, T.; Shirokova, G. The translation of entrepreneurial intention into start-up behaviour: The moderating role of regional social capital. Int. Small Bus. J. Res. Entrep. 2019, 37, 473-501. [CrossRef]

12. Pratono, A.H.; Saputra, R.S.; Pudjibudojo, J.K. The social capital and firm performance: Evident from Indonesia small businesses. Int. J. Econ. Financ. Issues 2016, 6, 47-50.

13. Kim, N.; Shim, C. Social capital, knowledge sharing and innovation of small- and medium-sized enterprises in a tourism cluster. Int. J. Contemp. Hosp. Manag. 2018, 30, 2417-2437. [CrossRef]

14. Harjanti, D.; Noerchoidah, N. The Effect of Social Capital and Knowledge Sharing on Innovation Capability. Jurnal Manajemen dan Kewirausahaan 2017, 19, 72-78. [CrossRef]

15. Garcia-Villaverde, P.M.; Rodrigo-Alarcon, J.; Ruiz-Ortega, M.J.; Parra-Requena, G. The role of knowledge absorptive capacity on the relationship between cognitive social capital and entrepreneurial orientation. J. Knowl. Manag. 2018, 22, 1015-1036. [CrossRef]

16. Matsongoni, H.; Mutambara, E. An assessment of informal SMEs' potential in an African economy-Theoretical and conceptual framework. Public Munic. Financ. 2018, 7, 1-13. [CrossRef]

17. Farida, N. Antecedent of Innovation and Marketing Performance in Batik Industry. Adv. Sci. Lett. 2017, 23, 471-474. [CrossRef]

18. Dastourian, B.; Kesim, H.K.; Amiri, N.S.; Moradi, S. Women entrepreneurship: Effect of social capital, innovation and market knowledge. AD-minister 2017, 115-130. [CrossRef]

19. Akintimehin, O.O.; Eniola, A.A.; Alabi, O.J.; Eluyela, D.F.; Okere, W.; Ozordi, E. Social capital and its effect on business performance in the Nigeria informal sector. Heliyon 2019, 5, e02024. [CrossRef] 
20. Nahapiet, J.; Ghoshal, S. Social capital, intellectual capital, and the organizational advantage. Acad. Manag. Rev. 1998, 23, 242-266. [CrossRef]

21. Kebede, G.F. Social Capital and Entrepreneurial Outcomes: Evidence from Informal Sector Entrepreneurs in Ethiopia. J. Entrep. 2018, 27, 209-242. [CrossRef]

22. Mungai, A.M.W.; Kihonge, E.; Gichure, J. Effect of Proactiveness on the Growth of Women Street Vending in Kenya. J. Entrep. Proj. Manag. 2019, 3, 35-63.

23. Mitra, J. Entrepreneurship, Innovation and Regional Development: An Introduction; Routledge: Abingdon, UK, 2019.

24. Galbreath, J. Drivers of Green Innovations: The Impact of Export Intensity, Women Leaders, and Absorptive Capacity. J. Bus. Ethics 2017, 158, 47-61. [CrossRef]

25. Sutcliffe-Braithwaite, F.; Lawrence, J. Power and Its Loss in The Iron Lady, in Biography and History in Film; Springer: Berlin/Heidelberg, Germany, 2019; pp. 295-317.

26. Iwu, C.G.; Nsengimana, S.; Robertson, T.K. The Factors Contributing to the Low Numbers of Women Entrepreneurs in Kigali; Acta Universitatis Danubius: Pécs, Hungary, 2019.

27. Yamaguchi, C.K.; Zanela, P.M.; Ezequiel, K.B.D.O.; Duminelli, M.V.; Lopes, G.S.C.; Da Silva, M.P. Process of Inter Organizational Knowledge Sharing and Women's Entrepreneurship. Int. J. Innov. Educ. Res. 2018, 6, 65-77. [CrossRef]

28. Vivek, V.; Saranya, S.; Chandrasekar, K. Tourism Development and Fundamentals to Promote Sustainopreneurship in Tourism Industry. Our Herit. 2020, 68, 10598-10603.

29. Giantari, I.G.A.K.; Surya, I.B.K.; Yasa, N.N.K.; Yasa, I.B.A.; Ketut, G.I.G.A. Development and revitalization strategies for traditional markets in Bali. Int. J. Soc. Econ. 2018, 45, 1058-1070. [CrossRef]

30. Perez, C.; Sokolova, K.; Konate, M. Digital social capital and performance of initial coin offerings. Technol. Soc. Chang. 2020, 152, 119888. [CrossRef]

31. Tsai, F.-S.; Hsu, I.-C. The effects of social capital on knowledge heterogeneity. Manag. Decis. 2019, 57, 1237-1253. [CrossRef]

32. Smith, C. An Analysis Of Structural Social Capital And The Individual's Intention To Share Tacit Knowledge Using Reasoned Action Theory. J. Appl. Bus. Res. 2017, 33, 475-488. [CrossRef]

33. Claridge, T. Social Capital and Natural Resource Management. Master's Thesis, University of Queensland, Brisbane, Australia, 2004.

34. Hernández-Carrión, C.; Camarero-Izquierdo, C.; Gutiérrez-Cillán, J. The internal mechanisms of entrepreneurs' social capital: A multi-network analysis. Bus. Res. Q. 2020, 23, 1047. [CrossRef]

35. Afriyie, S.; Du, J.; Ibn Musah, A.-A. Innovation and marketing performance of SME in an emerging economy: The moderating effect of transformational leadership. J. Glob. Entrep. Res. 2019, 9, 40. [CrossRef]

36. Bourdieu, P. The social space and the genesis of groups. Information 1985, 24, 195-220.

37. Putnam, R.D. Bowling Alone: America's Declining Social Capital. In Culture and Politics; Springer: Berlin/Heidelberg, Germany, 2000; pp. 223-234.

38. Wang, L.; Huang, M.; Liu, M. How founders' social capital affects the success of open-source projects: A resource-based view of project teams. Electron. Commer. Res. Appl. 2018, 30, 51-61. [CrossRef]

39. Jasmine, T.; Sameer, P. Immigrant family businesses: Social capital, network benefits and business performance. Int. J. Entrep. Behav. Res. 2015, 21, 842-866.

40. Grant, R.M. Toward a knowledge-based theory of the firm. Strat. Manag. J. 1996, 17, 109-122. [CrossRef]

41. Ozen, O. Social Capital, Knowledge Sharing and Innovation: The Role of Business Group Affiliation in Turkey. Ph.D. Thesis, University of Bath, Bath, UK, 2017.

42. Shahin, A.; Pool, J.K.; Amani, M. The effect of organisational factors of knowledge management on corporate entrepreneurship: An empirical investigation on Iranian sport organisations. Middle East J. Manag. 2014, 1, 330. [CrossRef]

43. Tsai, Y.-H.; Ma, H.-C.; Lin, C.-P.; Chiu, C.-K.; Chen, S.-C. Group social capital in virtual teaming contexts: A moderating role of positive affective tone in knowledge sharing. Technol. Soc. Chang. 2014, 86, 13-20. [CrossRef]

44. Pangil, F.; Chan, J.M. The mediating effect of knowledge sharing on the relationship between trust and virtual team effectiveness. J. Knowl. Manag. 2014, 18, 92-106. [CrossRef]

45. Sarkis, J.; Vazquez-Brust, D.; De Bruijn, T.; Fischer, K.; Franco-Garcia, M.L.; Kamolsiripichaiporn, S.; Kua, H.W.; Lehmann, M.; Kuppusamy, I. Helping to build a sustainable future through the greening of industry and its networks: Knowledge sharing and action promotion. J. Clean. Prod. 2015, 98, 8-16. [CrossRef] 
46. Nesheim, T.; Hunskaar, H.M. When employees and external consultants work together on projects: Challenges of knowledge sharing. Int. J. Proj. Manag. 2015, 33, 1417-1424. [CrossRef]

47. Chiu, Y.W.; Chien, Y.C. The Effects of Knowledge Management and Cloud Technology Involvement upon Organizational Performance: Intellectual Capital as a Dual Variable. J. Glob. Bus. Manag. 2015, 11, 94-112.

48. Halberstadt, J.; Timm, J.-M.; Kraus, S.; Gundolf, K. Skills and knowledge management in higher education: How service learning can contribute to social entrepreneurial competence development. J. Knowl. Manag. 2019, 23, 1925-1948. [CrossRef]

49. Yim, B.; Leem, B. The effect of the supply chain social capital. Ind. Manag. Data Syst. 2013, 113, 324-349. [CrossRef]

50. Agyapong, F.O.; Agyapong, A.; Poku, K. Nexus between social capital and performance of micro and small firms in an emerging economy: The mediating role of innovation. Cogent Bus. Manag. 2017, 4. [CrossRef]

51. Li, Y.; Ye, F.; Sheu, C. Social capital, information sharing and performance. Int. J. Oper. Prod. Manag. 2014, 34 , 1440-1462. [CrossRef]

52. Aristayudha, A.; Sudibia, G.A.; Supartha, I.W.G. The role of self-efficacy in mediating the effect of self-leadership on entrepreneur performance in young entrepreneur. IOSR J. Bus. Manag. 2018, 20, 47-52.

53. Muniady, R.; Al Mamun, A.; Mohamad, M.R.; Permarupan, P.Y.; Zainol, N.R.B. The Effect of Cognitive and Relational Social Capital on Structural Social Capital and Micro-Enterprise Performance. Sage Open 2015, 5. [CrossRef]

54. Yun, J.J.; Liu, Z. Micro- and Macro-Dynamics of Open Innovation with a Quadruple-Helix Model. Sustainability 2019, 11, 3301. [CrossRef]

55. Nsengimana, S.; Tengeh, R.K.; Iwu, C.G. The Sustainability of Businesses in Kigali, Rwanda: An Analysis of the Barriers Faced by Women Entrepreneurs. Sustainability 2017, 9, 1372. [CrossRef]

56. Berita, B. The Number of Entrepreneurs in Bali Increased to 326,000 MSMEs. Available online: https://www. beritasatu.com/ekonomi/541035-jumlah-wirausahawan-di-bali-meningkat-jadi-326000-umkm (accessed on 31 March 2020).

57. Berita, B. Denpasar Handicraft Products Attracts 2018 Inacraft Visitors. Available online: https://www.news. beritabali.com/read/2018/04/27/201804270011/produk-perajin-denpasar-diminati-pengunjung-inacraft-2018 (accessed on 11 March 2020).

58. Berita, S. Encourage Entrepreneurial Progress Through Training. Available online: https://www.liputan6.com/ citizen6/read/3924215/5-cara-menulis-daftar-pustaka-dari-internet-wajib-tahu-agar-tidak-salah (accessed on 10 March 2020).

59. Bisnis, B. 15 Denpasar IKM Trained Entrepreneurship in Industry and Trade: Entrepreneurs Success Because of Courage and Hard Work. Available online: http://bisnisbali.com/index.php/2017/08/02/15-ikmdenpasar-dilatih-kewirausahaan-disperindag-pengusaha-sukses-karena-berani-dan-kerja-keras/ (accessed on 11 March 2020).

60. Kompasiana. Digital Marketing Training for Women “Home Industry” Players in Denpasar City in 2019. Available online: https:/www.kompasiana.com/satyautami/5d27e4e4097f362855167714/pelatihan-digitalmarketing-bagi-pelaku-home-industri-perempuan-di-kota-denpasar-tahun-2019?page=all (accessed on 10 March 2020).

61. Balipost. Realizing Clean Bali with Innovative Products. Available online: http://www.balipost.com/news/ 2019/09/05/86204/Mewujudkan-Bali-Bersih-dengan-Produk...html (accessed on 11 March 2020).

(C) 2020 by the authors. Licensee MDPI, Basel, Switzerland. This article is an open access article distributed under the terms and conditions of the Creative Commons Attribution (CC BY) license (http://creativecommons.org/licenses/by/4.0/). 